\title{
Comparative study between biological treatment and a physicochemical treatment for the removal of Butyl Acetate in industrial residual effluents
}

\section{Estudio comparativo entre un tratamiento biológico y un tratamiento fisicoquímico para la remoción de Butil Acetato en efluentes residuales industriales}

\author{
CARRILLO-CABRERA, Roxana ${ }^{1} \dagger$, RODRIGUEZ-MORALES, Jose Alberto*2 ${ }^{* 2}$ LEDESMA-GARCIA, \\ Janet $^{2}$ and AMARO-REYES, Aldo ${ }^{1}$
}

${ }^{1}$ Facultad de Química de la Universidad Autónoma de Querétaro.

${ }^{2}$ Facultad de Ingeniería de la Universidad Autónoma de Querétaro

ID $1^{\text {st }}$ Author: Roxana, Carrillo-Cabrera / ORC ID: 0000-0003-2068-0835, CVU CONACYT ID: 248405

ID $1^{\text {st }}$ Co-author: Jose Alberto, Rodriguez-Morales / ORC ID: 0000 0002-4532-9665, CVU CONACYT ID: 200320

ID $2^{\text {nd }}$ Co-author: Janet, Ledesma-Garcia / ORC ID: 0000 0002-0677-4280, CVU CONACYT ID: 104183

ID $3^{\text {rd }}$ Co-author: Aldo, Amaro-Reyes / ORC ID: 0000 0001- 6520-5742, CVU CONACYT ID: 222109

DOI: $10.35429 / J O E S .2021 .24 .8 .9 .16$

Received: March 30, 2021; Accepted June 30, 2021

\begin{abstract}
A comparison was made between a fixed aerobic biological process and a physicochemical treatment for waste effluents with butyl acetate. An acrylic tank with $100 \mathrm{~L}$ capacity and a support medium for PET bottles was implemented for the formation of the biofilm and thus develop the biological reactor. In the experimental phase, concentrations of 10,20 and $30 \%$ of butyl acetate containing sample, using hydraulic retention times of: $(16,8,5.33$ and 4 days) for each concentration. After the experimentation, a removal of $99 \%$ of COD and $97 \%$ of BOD was obtained. For the physicochemical treatment, coagulant, flocculant, and adjuvants were used, by a jar test. A decrease in $74 \%, 53.8 \%$, $55 \%, 97 \%$ and $37 \%$, for electrical conductivity, total suspended solids, color, turbidity, COD and BOD respectively, were obtained compared to the initial sample. Both treatments were filtered through a bed packed with activated carbon, sand, and silica gravel. The aim of this work was to evaluate / quantify butyl acetate removal efficiency in each treatment for its subsequent comparison, with prospect to the reduction of similar pollutants in residual effluents is intended.
\end{abstract}

Biological treatment, Physicochemical treatment, Butyl acetate

\begin{abstract}
Resumen
Se realizó una comparación entre un proceso biológico aerobio fijo y un tratamiento fisicoquímico para efluentes residuales con butil acetato. Para el desarrollo del reactor biológico se implementó un tanque de acrílico con capacidad de $100 \mathrm{~L}$ y un medio de soporte de botellas PET para la formación del biofilm, en la parte experimental se manejaron concentraciones de 10, 20 y $30 \%$ de la muestra con butil acetato, empleando tiempos de retención hidráulica de: $(16$, $8,5.33$ y 4 días) para cada concentración. Finalizada la experimentación se obtuvo una remoción del 99\% de DQO y $97 \%$ de DBO. Para el tratamiento fisicoquímico se empleó coagulante, floculante y coadyuvantes, mediante una prueba de jarras. Obteniendo como resultados la disminución en un $74 \%, 53.8 \%, 55 \%, 97 \%$ y 37\%, para conductividad eléctrica, solidos suspendidos totales, color, turbidez, DQO y DBO respectivamente, en comparación a la muestra inicial. Ambos tratamientos se filtraron mediante un lecho empacado con carbón activado, arena y grava sílica. El objetivo del presente trabajo fue evaluar/cuantificar la eficiencia de remoción del butil acetato en cada tratamiento para su posterior comparación, por lo cual se pretende la reducción de contaminantes similares en efluentes residuales.
\end{abstract}

Tratamiento biológico, Tratamiento fisicoquímico, Butil acetato

Citation: CARRILLO-CABRERA, Roxana, RODRIGUEZ-MORALES, Jose Alberto, LEDESMA-GARCIA, Janet and AMARO-REYES, Aldo. Comparative study between Biological treatment and a physicochemical treatment for the removal of Butyl Acetate in industrial residual effluents. Journal of Experimental Systems. 2021. 8-24: 9-16

\footnotetext{
* Author Correspondence (josealberto970@ hotmail.com)

$\dagger$ Researcher contributing as first author.
} 


\section{Introducción}

Surface water and groundwater pollution is reported at $24 \%$ and $4 \%$ respectively, which has been generated by high concentrations of various chemical species. These come from diffuse sources of pollution (use of pesticides, manure production in agriculture) and specific sources (industrial landfills, as well as in industrial mining practices).

Effluents from industrial processes contain toxic products, harmful organic compounds, and metals, of varying composition, type and concentration, depending on the processes that generate them. Natural organic compounds in the environment tend to naturally degrade slowly into less harmful components, however, volatile organic compounds (VOCs) found in effluents from industrial processes are not considered biodegradable.

VOCs are used in the manufacture of paints, varnishes, waxes and are chemical industry's main organic pollutants used as solvents, being butyl acetate (C6H12O2), most widely used, as a solvent in polyurethane resins and paints (stripping) for special applications. It is a colorless liquid with a fruity odor, soluble in organic solvents, highly flammable, and dangerous to health, affecting the central nervous system.

It has been reported in various studies that water contaminated with compounds like butyl acetate, such as ethyl tert-butyl ether $\left(\mathrm{C}_{6} \mathrm{H}_{14} \mathrm{O}\right)$, methyl tert-butyl ether $\left(\mathrm{C}_{5} \mathrm{H}_{12} \mathrm{O}\right)$, tertamyl methyl ether (C6H14O) and diisopropyl ether $(\mathrm{C} 6 \mathrm{H} 14 \mathrm{O})$, have been treated by using microorganisms in a biodegradation process. Because it is a slow process, the addition of specific bacteria selected for their efficiency in removing contaminants has been implemented.

\section{Residual water}

Wastewater can be classified according to its origin: industrial, commercial, and domestic sector, in some cases adequate treatments are not implemented for its reuse, which, depending on current regulations and the economic interest of each company, is the importance given to the treatment process.
The pollutants concentration present in wastewater varied according to the origin of the sample and industrial use, suspended solids, organic matter, oils, fats, nitrogen, and phosphorus can be found. Membrane activated carbon filtration and chemical precipitation techniques are the most used for its recovery.

\section{Types of wastewater treatment}

The treatments most used in wastewater purification processes are primary, secondary, and tertiary, the conditions, on which, the choice of a treatment is based are the flow rate to treat, the concentration of pollutants, the type of pollutants, the place weather and the continuity in the raw water supply, the treatments are described below:

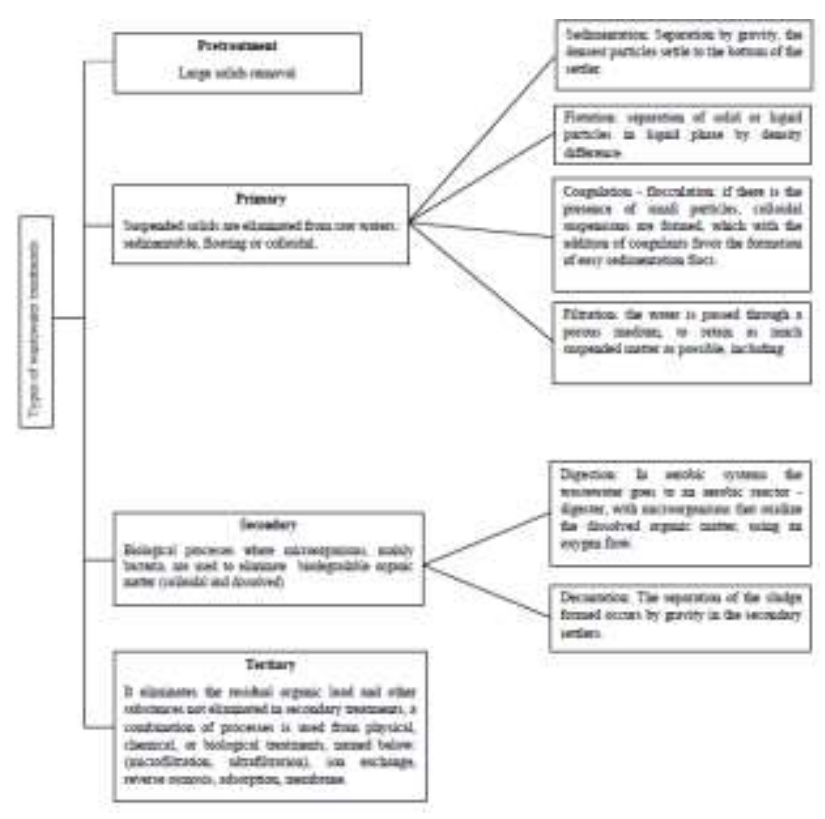

Figure 1 General water treatment diagram Own Elaboration

Another treatment is disinfection, which consists of eliminating or inactivating pathogenic microorganisms or any other living microorganism to ensure the reuse of treated water. The main disinfection processes are chlorination, ozonation, electro-disinfection.

\section{Methodology \\ Reactor development}

A $100 \mathrm{~L}$ capacity acrylic tank was used, with the following dimensions $(60 \mathrm{~cm} \times 56 \mathrm{~cm} \times 30 \mathrm{~cm})$, which was adapted as a reactor. Two valves were placed after the feed inlet, a sphere type with a diameter of 1.5 inches, flow $3.95 \mathrm{~L} \mathrm{sec}^{-1}$, to regulate the feed flow of the affluent through the upper and lower part of the reactor. 
To regulate the effluent outflow and the biomass purge, two ball valves were used as previously described. The sludge was recirculated with a MAXIMA® aeration pump for $113.6 \mathrm{~L}$, which were connected to three 45 $\mathrm{cm}$ long porous rubber diffuser hoses, fish tank type to maintain a dissolved oxygen concentration of 3-4 $\mathrm{mg} \mathrm{L}^{-1}$ arranged at the bottom of the tank.

\section{Support medium}

108 polyethylene terephthalate (PET) bottles of different capacities $(2,1$ and $0.5 \mathrm{~L})$ with holes were used to facilitate air flow. They were placed concentrically (they were assembled from smaller to larger capacity) and were distributed in an organized way in the bioreactor to allow the flow of the water, thus avoiding the obstruction of this, to increase the contact surface and the development of the biofilm, such as can be seen in Figure 2 .

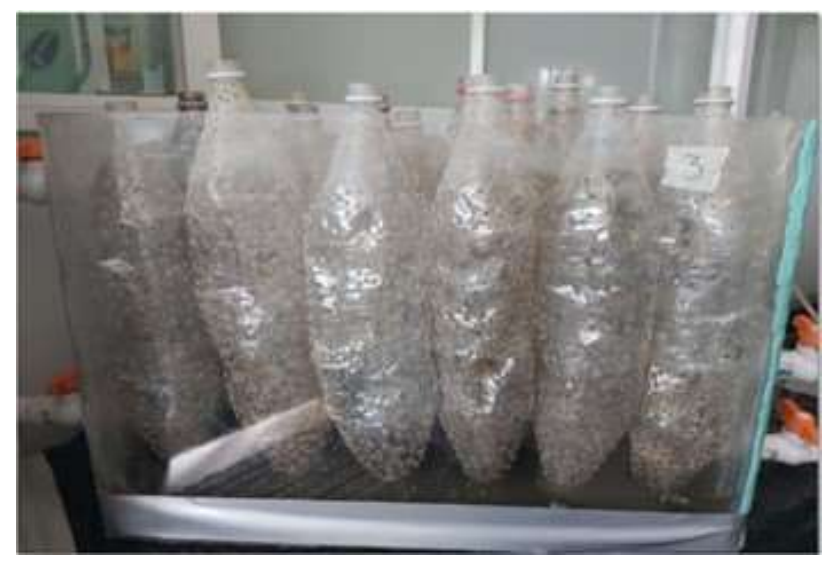

Figure 2 Fixed aerobic biological reactor prototype

\section{Biological process development}

For the formation of the biofilm in the reactor, 3 $\mathrm{L}$ of activated sludge inoculum from the treatment plant of the Autonomous University of Querétaro, Airport campus, were used. The sludge was fed with residual water from the same plant of the institution collected from laboratories and bathrooms, for a period of 1 to 6 months for maintenance, adaptation, and formation of biofilm in the PET support, as observed in Figure 3.

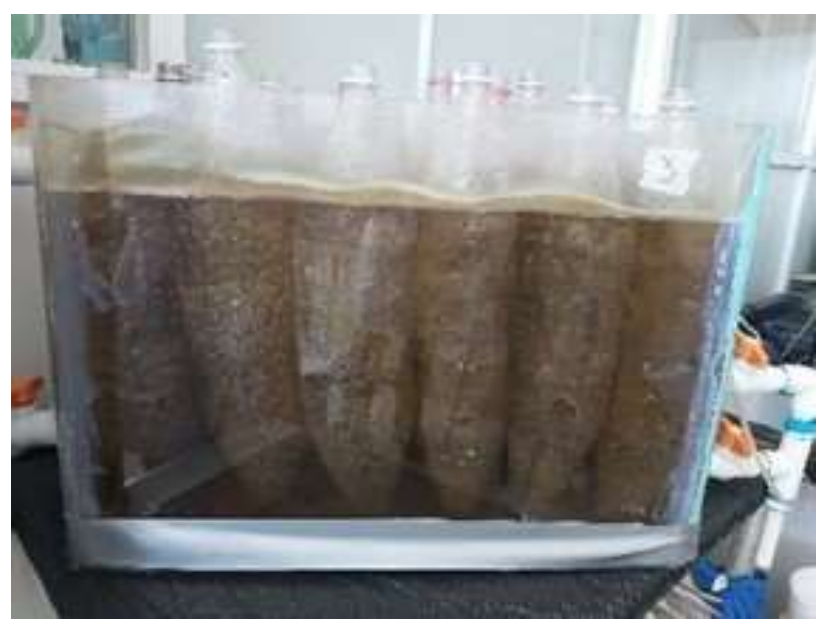

Figure 3 Biofilm formation

After establishing the biofilm and being able to guarantee the efficiency of the system in reducing nutrients, BOD / COD degradation and $\mathrm{pH}$ stabilization, the effluent quality analysis was carried out to verify compliance with NOM003-ECOL-1997 and NOM-001-SEMARNAT96.

\section{Biokinetic coefficients}

To evaluate the efficiency of the reactor and the stabilization of the biomass, the biokinetic coefficients were determined (Equation 1), which indicate the growth of the biomass, the use rate of the substrate, the food-microorganism relationship, and the mean time of cell retention. Equation to calculate the mean speed constant (Ks).

$\frac{\theta \mathrm{X}}{\mathrm{S}_{0}-\mathrm{S}}=\frac{\mathrm{K}_{\mathrm{S}}}{(\mathrm{k})(\mathrm{S})}+\frac{1}{\mathrm{k}}$

Where:

$\theta=$ hydraulic retention time $(\mathrm{h})$

$\mathrm{X}=$ concentration of volatile suspended solids in the mixed liquor, L / h, mg VSS ML / L / h

$\mathrm{S}_{0}=$ concentration of soluble COD in influent (mg L ${ }^{-1}$ )

$\mathrm{S}=$ concentration of soluble COD in effluent $\left(m g L^{-1}\right)$

$\mathrm{k}=$ maximum substrate utilization rate $(\mathrm{h})$

$\mathrm{Ks}=$ mean speed constant $\left(\mathrm{mg} \mathrm{L}^{-1}\right)$

Equation 2 to calculate maximum cell yield $(\mathrm{Y})$ and endogenous decay coefficient $(\mathrm{kd})$

$\frac{1}{\theta_{\mathrm{C}}}=\mathrm{Y} \frac{\mathrm{s}_{0}-\mathrm{S}}{\mathrm{X} \theta}-\mathrm{k}_{\mathrm{d}}$

Where:

$\mathrm{Y}=$ maximum cell yield

$\mathrm{kd}=$ endogenous decay coefficient, $\mathrm{h}^{-1}$ 
Subsequently, contaminant elimination from the test sample was sought using microorganisms adapted to the residual water in the reactor in a period of 1 to 6 months.

\section{Calculation of the contact area of the biofilm}

To calculate the contact area of the microorganisms to the PET support, the following equations were used for the truncated cone (3) and cylinder (4):

$A=\pi\left(R_{1}^{2}+R_{2}^{2}+a\left(R_{1}+R_{2}\right)\right)$

$A_{\mathrm{c}}=b \times h=(2 \pi \mathrm{r})(\mathrm{h})$

\section{Adaptation of the effluent aerobic biological process (ABP) with butyl acetate}

For the beginning of this adaptation stage, it was carried out by adding the effluent with butyl acetate to the biological reactor. Three concentrations were used $(10,20$ and $30 \%)$ diluted in residual water, the process was carried out for four months, as shown in Figure 4 and 5.

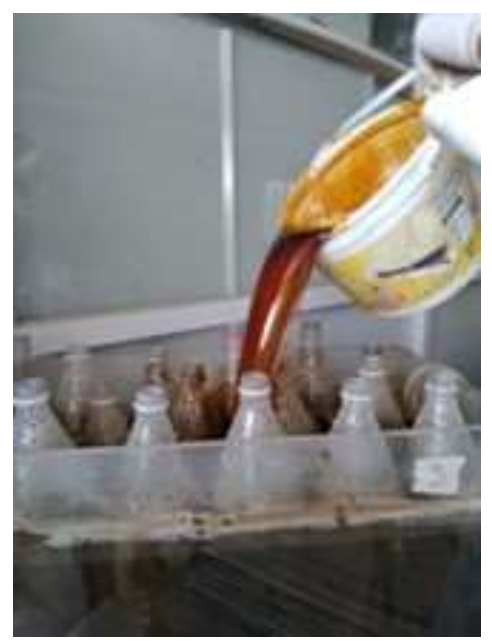

Figure 4 Biological reactor feeding with domestic wastewater and effluent with butyl acetate mixture

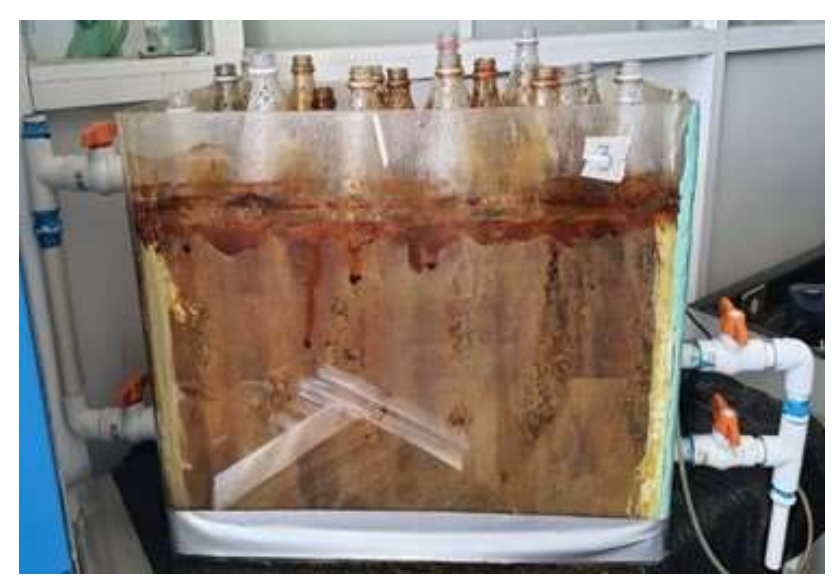

Figure 5 Biological reactor adaptation to the effluent with butyl acetate

\section{Hydraulic retention times}

The different hydraulic retention times applied were $16,8,5.33$ and 4 days for each of the concentrations used $(10,20$ and $30 \%)$ of wastewater and effluent with butyl acetate.

\section{Deveopment of the physicochemical process}

For the physicochemical process, 10 experiments were carried out using the jar test for the coagulant, flocculant, and adjuvants, which were carried out on a shaker (PHIPPS \& BIRD, USA), for testing 6-place jars with six 1 $\mathrm{L}$ beakers, the stirring time was $5 \mathrm{~min}$ at 150 $\mathrm{rpm}$. The initial $\mathrm{pH}$ of the samples was 3.6.

Table 1 summarizes the methodology applied, as well as the concentrations used in the reagents to perform the jar tests.

\begin{tabular}{|l|l|}
\hline Test & \multicolumn{1}{c|}{ Conditions } \\
\hline 1 & $\begin{array}{l}\text { pH 3.6-9,45 ml chemical lime (20\%), 5 ml metal } \\
\text { precipitator (1\%), 2 ml coagulant 90/10 (10\%), 5 } \\
\text { ml flocculant 70/24 (1\%) }\end{array}$ \\
\hline 2 & $\begin{array}{l}\text { pH 3.6-2, 1.8 ml of H2SO4 (98\%), 2 ml metal } \\
\text { precipitator (1\%), pH 7, 45 ml chemical lime } \\
(20 \%), 2.5 \mathrm{ml} \text { coagulant 90/10 (10\%), 1.3 ml } \\
\text { flocculant 70/24 (1\%) }\end{array}$ \\
\hline 3 & $\begin{array}{l}\text { pH 3.6- 6, 30 ml chemical lime (20\%), 3 ml } \\
\text { metal precipitator (1\%), 1.5 ml coagulant 90/10 } \\
(10 \%), 2 \mathrm{ml} \text { flocculant 70/24 (1\%) }\end{array}$ \\
\hline 4 & $\begin{array}{l}\text { pH 3.6- 8, 40 ml chemical lime (20\%), 7 ml } \\
\text { metal precipitator (1\%), 4 ml coagulant 90/10 } \\
(10 \%), 7 \text { ml flocculant 70/24 (1\%) }\end{array}$ \\
\hline 5 & $\begin{array}{l}\text { pH 3.6-1, 2.8 ml H2SO4 (98\%), 3 ml metal } \\
\text { precipitator (1\%), pH 7, 60 ml chemical lime } \\
(20 \%), 2 \mathrm{ml} \text { coagulant 90/10 (10\%), 8 ml of } \\
\text { flocculant 70/24 (1\%) }\end{array}$ \\
\hline
\end{tabular}

Table 1 Conditions applied at jar tests

\section{Filtration system}

A $60 \mathrm{~cm}$ acrylic column and a diameter of $10 \mathrm{~cm}$ was run. It was packed with activated carbon, sand, and silica gravel 1-1 1/2 cm, using layers of $15 \mathrm{~cm}$ of each, the result obtained is shown in Figure 6. 


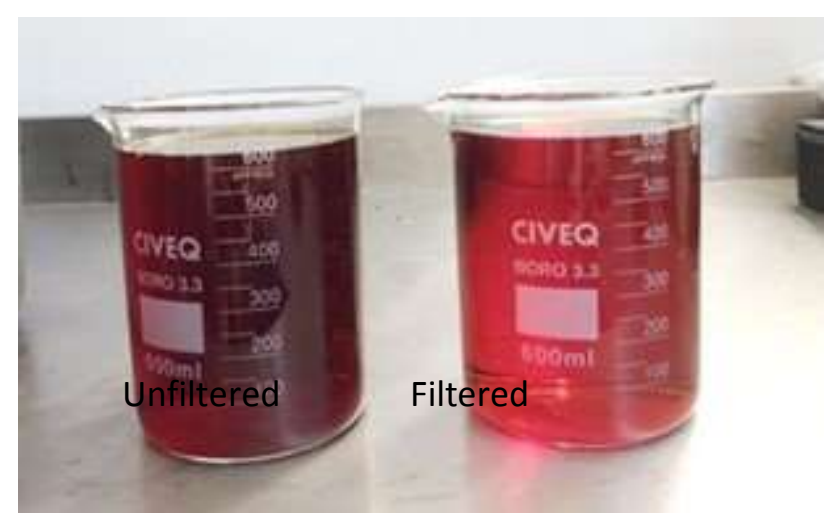

Figure 6 Physicochemically treated sample before and after filtration

The samples after the biological and physicochemical treatment were subjected to a filtration process and the result is shown in Figure 7.

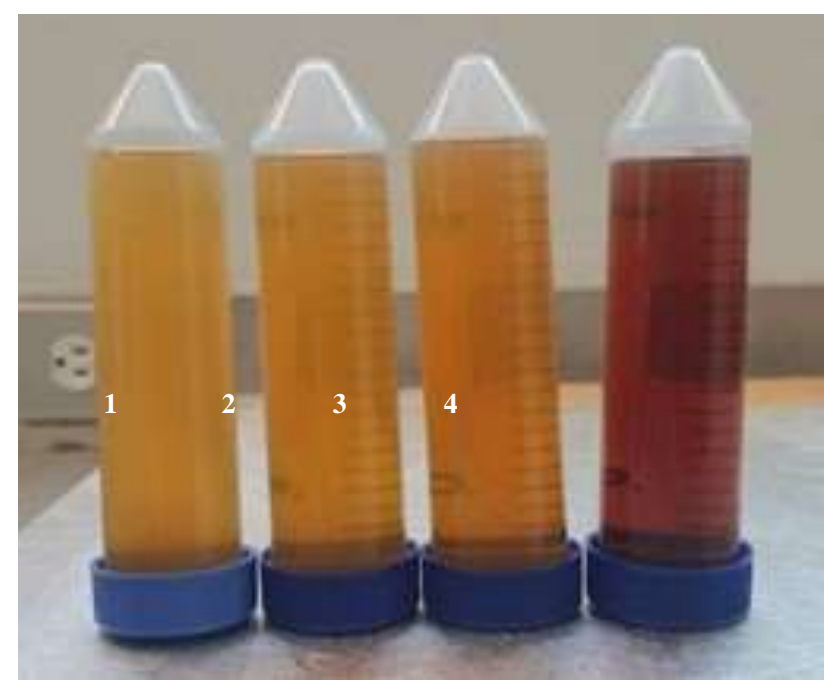

Figure 7 Filtered samples after biological treatment (1, 2 and 3) and physicochemical treatment (4)

\section{Analytical techniques}

The analyzes of $\mathrm{pH}$, conductivity, chemical oxygen demand (COD), total dissolved solids (TDS), total solids (ST) and color (Pt-Co), were applied for both treatments.

\section{Results}

Biological treatment: Domestic wastewater characterization

\begin{tabular}{|l|l|l|}
\multicolumn{1}{|c}{ Parameter } & \multicolumn{1}{c|}{$\begin{array}{c}\text { Value } \\
\text { obtained }\end{array}$} & \multicolumn{1}{c|}{$\begin{array}{c}\text { Maximum } \\
\text { allowable limit }\end{array}$} \\
\hline Temperature ${ }^{\circ} \mathrm{C}$ & 25.5 & $40{ }^{\circ} \mathrm{C}$ \\
\hline Fats and Oils & 25 & $25 \mathrm{mg} / \mathrm{L}$ \\
\hline Floating Matter & Ausente & Ausente \\
\hline Settling Solids & 3 & $2 \mathrm{mg} / \mathrm{L}$ \\
\hline $\begin{array}{l}\text { Total Suspended } \\
\text { Solids }\end{array}$ & 500 & $60 \mathrm{mg} / \mathrm{L}$ \\
\hline $\begin{array}{l}\text { Biochemical } \\
\text { Oxygen Demand }\end{array}$ & 600 & $60 \mathrm{mg} / \mathrm{L}$ \\
\hline Total Nitrogen & 50 & $25 \mathrm{mg} / \mathrm{L}$ \\
\hline Total Phosphorous & 20 & $10 \mathrm{mg} / \mathrm{L}$ \\
\hline Arsenic & N.D. & $0.2 \mathrm{mg} / \mathrm{L}$ \\
\hline Cadmium & N.D. & $0.2 \mathrm{mg} / \mathrm{L}$ \\
\hline Cianide & N.D. & $2.0 \mathrm{mg} / \mathrm{L}$ \\
\hline Copper & N.D. & $6.0 \mathrm{mg} / \mathrm{L}$ \\
\hline Chromium & N.D. & $1.00 \mathrm{mg} / \mathrm{L}$ \\
\hline Mercury & N.D. & $0.01 \mathrm{mg} / \mathrm{L}$ \\
\hline Níckel & N.D. & $4.0 \mathrm{mg} / \mathrm{L}$ \\
\hline Lead & N.D. & $0.4 \mathrm{mg} / \mathrm{L}$ \\
\hline Zinc & N.D. & $20 \mathrm{mg} / \mathrm{L}$ \\
\hline
\end{tabular}

Table 2 Characterization of NOM-001 SEMARNAT 1996

\begin{tabular}{|l|l|l|}
\multicolumn{1}{|c}{ Parameter } & \multicolumn{1}{c}{$\begin{array}{c}\text { Value } \\
\text { obtained }\end{array}$} & \multicolumn{1}{c|}{$\begin{array}{c}\text { Maximum allowable } \\
\text { limit }\end{array}$} \\
\hline $\begin{array}{l}\text { Fecal } \\
\text { coliforms }\end{array}$ & $\begin{array}{l}\geq 2400000 \\
\text { NMP }\end{array}$ & $240 \mathrm{NMP} / 100 \mathrm{ml}$ \\
\hline Helmith eggs & $<1$ & $<1(\mathrm{~h} / 1)$ \\
\hline Fats and oils & 25 & $15 \mathrm{~m} / \mathrm{l}$ \\
\hline BOD 5 & 594 & $20 \mathrm{mg} / \mathrm{l}$ \\
\hline TSS & 500 & $20 \mathrm{mg} / \mathrm{l}$ \\
\hline
\end{tabular}

Table 3 Characterization of NOM-003 SEMARNAT 1997

\section{Biokinetic constant}

Obtaining the Chemical Oxygen Demand (S) and Volatile Suspended Solids (X), associated with the calculation of the biokinetic coefficients, shown in Table 4.

\begin{tabular}{|l|c|r|rr|r|}
\hline \multirow{2}{*}{ Cycle } & \multicolumn{1}{c}{$\mathbf{S}_{\mathbf{0}}$} & \multicolumn{1}{c|}{$\mathbf{S}$} & \multicolumn{1}{c|}{$\boldsymbol{\theta}=\boldsymbol{\theta}_{\mathbf{c}}$} & \multicolumn{1}{c|}{$\mathbf{X}$} \\
& $\mathrm{g} / \mathrm{L} \mathrm{COD}$ & $\mathrm{g} / \mathrm{L}$ COD & $\mathrm{h}$ & $\mathrm{g}$ VSS/L \\
\hline 1 & 0.795 & -- & 0 & 5.00 \\
\hline 2 & -- & 0.284 & 1 & 4.86 \\
\hline 3 & -- & 0.176 & 2 & 4.53 \\
\hline 4 & -- & 0.154 & 4 & 3.5 \\
\hline 5 & -- & 0.138 & 8 & 2.30 \\
\hline
\end{tabular}

Table 4 Chemical Oxygen Demand (S) and Volatile Suspended Solids (X)

To obtain the maximum substrate utilization rate $(\mathrm{k})$ and the average speed constant (Ks), the data obtained from Table 5 was first plotted with calculations of the equation $\mathrm{Y}$. 


\begin{tabular}{|l|c|l|}
\multicolumn{1}{c}{$\begin{array}{c}\mathbf{X \theta} \\
\mathbf{g} \mathbf{V S S} / \mathbf{h}\end{array}$} & $\begin{array}{c}\mathbf{1} / \mathbf{S} \\
(\mathbf{h})^{-\mathbf{1}}\end{array}$ & $\begin{array}{c}\mathbf{X \theta} /\left(\mathbf{S}_{\mathbf{0}}-\mathbf{S}\right) \\
\mathbf{h}^{-1}\end{array}$ \\
\hline 4.86 & 3.533 & 9.0005 \\
\hline 9.06 & 5.6818 & 14.3711 \\
\hline 14 & 6.4935 & 16.4003 \\
\hline 18.4 & 7.2463 & 18.2825 \\
\hline
\end{tabular}

Table 5 Variables associated with the calculation of $\mathrm{k}$ and Ks

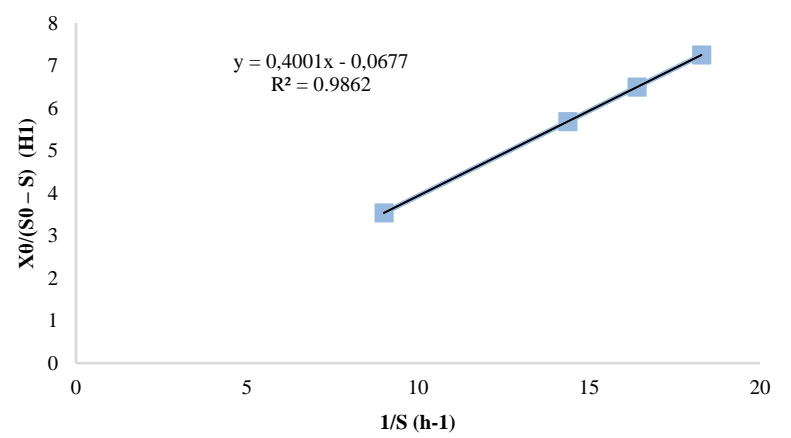

Figure 8 Maximum growth rate (k) and Average growth rate $(\mathrm{Ks})$

Figure 8 is the graph of $\mathrm{X} \theta /(\mathrm{S} 0-\mathrm{S})$ according to $1 / \mathrm{S}$. In this graph the ordinate to the origin is $1 / \mathrm{k}$, and the slope is equal to $\mathrm{Ks} /$ $\mathrm{k}$. Thus, obtaining $\mathrm{k}$ and $\mathrm{Ks}$ were $5.91 \mathrm{~h}^{-1}$ and $14.78 \mathrm{~g} / \mathrm{L}$ respectively.

\section{Maximum cell yield (Y) and endogenous decay coefficient $(k d)$}

The variables $1 / \theta \mathrm{c}$ and $\left(\mathrm{S}_{0}-\mathrm{S}\right) / \mathrm{X} \theta$ were obtained based on the data shown in table 6 . The graph of these results to obtain the biokinetic coefficients: Maximum cell yield (Y) and the endogenous decay coefficient $(\mathrm{kd})$ is shown in Figure 9.

\begin{tabular}{|l|l|}
\hline $\begin{array}{c}\mathbf{1} / \mathbf{\theta}_{\mathbf{c}} \\
\mathbf{h}^{-\mathbf{1}}\end{array}$ & $\begin{array}{c}\left(\mathbf{S}_{\mathbf{0}}-\mathbf{S}\right) / \mathbf{X} \boldsymbol{\theta} \\
\mathbf{h}^{-1}\end{array}$ \\
\hline 1 & 0.112 \\
\hline 0.5 & 0.067 \\
\hline 0.25 & 0.048 \\
\hline 0.125 & 0.037 \\
\hline
\end{tabular}

Table 6 Variables associated with the calculation of $\mathrm{Y}$ and $\mathrm{Kd}$

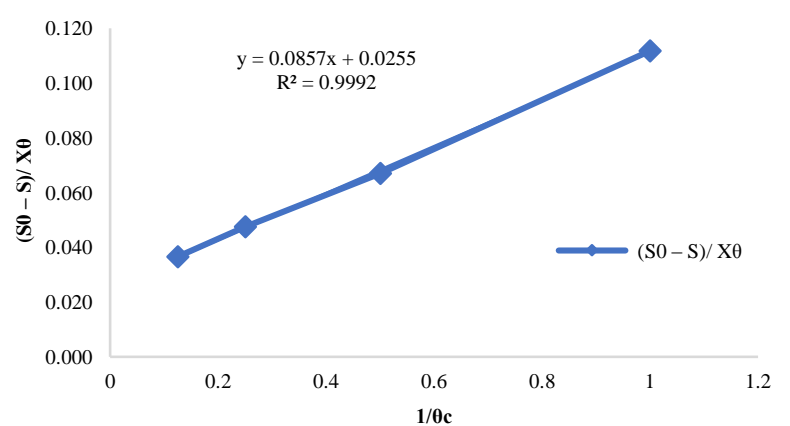

Figure 9 Maximum cell yield (Y) and endogenous decay coefficient $(\mathrm{kd})$

\begin{tabular}{|l|r|}
\hline \multicolumn{1}{|c}{ Coefficients } & \multicolumn{1}{c|}{$\begin{array}{c}\text { Result } \\
\text { obtained }\end{array}$} \\
\hline $\begin{array}{l}\text { Substrate utilization rate (k) g CODs / } \\
\text { gVSS }\end{array}$ & 5.91 \\
\hline Average rate constant (Ks) mg / 1 CODs & 14.78 \\
\hline $\begin{array}{l}\text { Maximum cell yield (Y) mg VSS / mg } \\
\text { CODs }\end{array}$ & 0.085 \\
\hline $\begin{array}{l}\text { Endogenous decay coefficient (kd) g SSV } \\
\text { /g VSS }\end{array}$ & 0.025 \\
\hline
\end{tabular}

Table 7 Results obtained from the biokinetic coefficients of the biological reactor

Once 1 / $\theta$ c was graphed with respect to $(\mathrm{S} 0-\mathrm{S}) / \mathrm{X} \theta$, the ordinate to the origin kd was obtained and the slope is Y. Consequently, the values of $\mathrm{Y}$ and $\mathrm{kd}$ that were obtained were 0.085 and $0.025 \mathrm{~h}-1$ respectively.

\section{Biofilm formation}

The sum of the area of the truncated cone and the cylinder resulted in $0.604262 \mathrm{~m}^{2}$ and the total contact area of the system for the reactor was $10.272454 \mathrm{~m}^{2}$.

\section{Hydraulic retention}

The parameters established in NOM 003 SEMARNAT 1997 were analyzed for the different hydraulic retention times in each concentration, as shown in Table 8 (a, b and c).

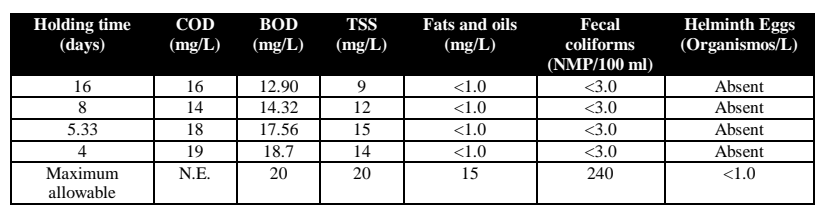

Table 8 a $10 \%$ concentration

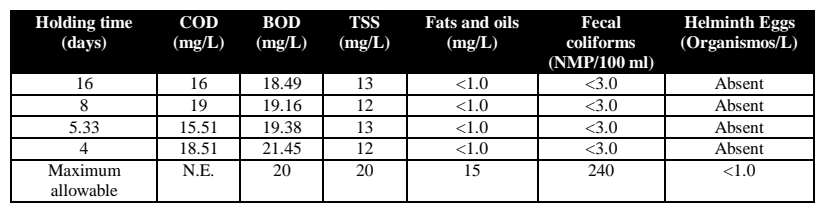

Table 8 b $20 \%$ concentration

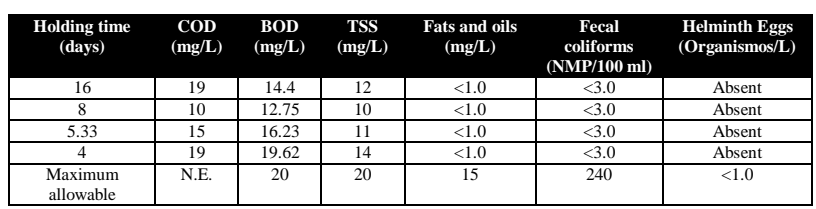

Tabla 8 c $30 \%$ concentration

\section{Physicochemical treatment}

The results are shown in Table 9, of the parameters characterized before and after the physicochemical treatment. 


\begin{tabular}{|l|l|r|r|}
\multicolumn{1}{c}{ Parameter } & \multicolumn{1}{c}{ Unit } & Initial result & Final result \\
\hline Electric conductivity & $\mu \mathrm{S}$ & 13925 & 7298 \\
\hline Total suspended solids & $\mathrm{mg} / \mathrm{L}$ & 1390 & 360 \\
\hline Color & $\mathrm{Pt}-\mathrm{Co}$ & 934 & 432 \\
\hline Turbidity & $\mathrm{NTU}$ & 756 & 340 \\
\hline COD & $\mathrm{mg} / \mathrm{L}$ & 35720 & 959 \\
\hline $\mathrm{BOD}$ & $\mathrm{mg} / \mathrm{L}$ & 900 & 300 \\
\hline $\mathrm{pH}$ & $\mathrm{N} / \mathrm{A}$ & 3.2 & 7 \\
\hline
\end{tabular}

Table 9 Industrial wastewater characterization

\section{Conclusions}

\section{Physicochemical treatment}

The parameters analyzed after treatment were decreased by $74 \%, 53.8 \%, 55 \%, 97 \%$ and $67 \%$, for electrical conductivity, total suspended solids, color, turbidity, COD and BOD respectively, compared to the initial sample.

\section{Biological treatment}

The parameters analyzed in the different hydraulic retention times in the experimental part for COD was $99 \%$. As well as they also present the values of BOD 97\%, for all the values. Regarding compliance with NOM 003 SEMARNAT 1997, all retention times comply except for the retention time of 3.2 days for the $30 \%$ concentration with wastewater and effluent with butyl acetate

In both treatments there was COD reduction, which indicates that there is a significant removal percentage for butyl acetate. The comparison of the treatments applied to the effluent showed that the biological treatment presented greater removal of the pollutant before the physicochemical treatment in $2 \%$ of COD and $30 \%$ of BOD.

\section{Discussion}

A mass coupled gas spectroscopy analysis is recommended to confirm the removal of butyl acetate in the effluent or the transformation into other chemical species.

\section{References}

Adin A., Rebhun M. 1974. High-rate contact flocculation-filtration with cationic polyelectrolytes. Journal American water Works association. 66(2).

Arboleda, J. 2000. Teoría y práctica de la purificación del agua, tercera edición (Tomo. I), McGraw-Hill.
Bartling, J., Esperschützb, J., Wilkea, B., Schloterb, M. 2011. ETBE (ethyl tert butyl ether) and TAME (tert amyl methyl ether) affect microbial community structure and function in soils. Journal of Hazardous Materials. 187 (1-3) 488-494.

Burguete M. Y. (2016). Acoplamiento de un sistema biológico aerobio y un proceso avanzado de oxidación para el tratamiento de un efluente acuoso, (Tesis Maestría en Ciencia y Tecnología Ambiental). Universidad Autónoma de Querétaro. México. 72p

Castellani, B., Morini, E., Filipponi, M., Nicolini, A., Palombo, M., Cotana, F., Rossi, F. 2014. Comparative analysis of monitoring devices for particulate content in exhaust gases. Sustainability. 6(7): 4287-4307.

Cleasby, J. 1969. Approaches to a filterability index for granular filters. Journal American Water Works Association. 61(8):372.

Comisión Nacional del Medio Ambiente (CONAMA). 1998. Política ambiental para el desarrollo sustentable, Chile.

Davis, M. 2010. Water and wastewater engineering: Design principles and practice. https://www.accessengineeringlibrary.com/cont ent/book/9780071713849

González, M. (2015). División de un sedimentador.

http://www.tratamientodelagua.com.mx/teoriade-sedimentacion/

Hernández, M., Gonzáles, N. 1993. Recursos hídricos y ambiente. En: Elementos de política ambiental. Cámara de Diputados de la Provincia de Buenos Aires, Argentina. Pg. 175-184.

Kirk, R., Othmer, D., Grayson, M., Eckroth, D. 1981. Kirk-Othmer Encyclopedia of Chemical Technology, 3rd ed.; John Wiley: New York, NY, USA, p. 664.

Kobe, K. 1958. Unit Processes in Organic Syntheses (Groggins, P. H.). Journal of Chemical Education. 35(11):584.

Manahan, S. 2011. Introducción a la química ambiental. Editorial Revérte, UNAM. México. Pág. 36-42,172-173, 205-214, 217-218, 228230. 
Mastroianni, N., López-García, E., Postigo, C., Barceló, D., López de Alda, M.2017. Five-year monitoring of 19 illicit and legal substances of abuse at the inlet of a wastewater treatment plant in Barcelona (NE Spain) and estimation of drug consumption patterns and trends. Science of The Total Environment. 609:916-926.

Mendoza, B. 2016. Acoplamiento de un sistema biológico aerobio a un proceso avanzado de oxidación para el tratamiento de un efluente acuoso. Tesis de maestría. Universidad Autónoma de Querétaro. México.

Metcalf, L., Eddy, H. 2003. Ingeniería de aguas residuales. Editorial McGraw-Hill. 53-59.

Metcalt y Eddy.1995. Ingeniería de las aguas residuales (vol. I), Madrid: McGraw-Hill.

Mihelcic, J., Zimmerman, J. 2011. Ingeniería ambiental. Fundamentos, sustentabilidad, diseño. Editorial Alfaomega. Pg. 65-85, 310322.

Nolasco, T., 2013. Cinética de crecimiento celular: Ecuación de Monod. [En línea] Universidad Autónoma del Estado de México, 2003. [Citado el: 11 de 11 de 2016.] http://es.slideshare.net/edya69/ecuacin-demonod-copia.

Norma Oficial Mexicana NOM-001SEMARNAT-1996, que establece los límites máximos permisibles de contaminantes en las descargas de aguas residuales en aguas y bienes nacionales.

https://www.profepa.gob.mx/innovaportal/file/3 290/1/nom-001-semarnat-1996.pdf

Norma Oficial Mexicana NOM-003SEMARNAT-1997, que establece los límites máximos permisibles de contaminantes para las aguas residuales tratadas que se reúsen en servicios al público. https://www.gob.mx/cms/uploads/attachment/fi le/110523/NOM_003_SEMARNAT_1997.pdf

The national Institute for occupational safety and health (NIOSH). 2019. Pocket Guide to Chemical Hazards.
Thornton, F., Nichollsa, G., Rolfeb, A., Mallinsona, H., Spencec, J. 2020. Biodegradation and fate of ethyl tert-butyl ether (ETBE) in soil and groundwater: A review. Journal of Hazardous Materials. 391:122046

Tuset, S. 2018. Sistemas con reactores aeróbicos para tratar aguas residuales. Condorchem Envitech Smart ideas for wastewater and air treatment. 